\title{
Hook Plating versus Tension Band Wiring in Treatment of Displaced Lateral End Clavicle Fracture
}

\author{
Alaa Abd elmaksoud El mohamady ${ }^{1, *}$ MSc, Ismail Ahmed Hammouda ${ }^{1}$ MD, Ehab El zahed ${ }^{1}$ MD
}

\author{
* Corresponding Author: \\ Alaa Abd elmaksoud \\ alaaelmohamady2000@gmail.com
}

Received for publication October 14, 2021; Accepted December 10, 2021;

Published online December 10, 2021.

Copyright The Authors published by Al-Azhar University, Faculty of Medicine, Cairo, Egypt. Users have the right to read, download, copy, distribute, print, search, or link to the full texts of articles under the following conditions: Creative Commons Attribution-Share Alike 4.0 International Public License (CC $B Y-S A$ 4.0)

doi: $10.21608 /$ aimj.2021.99277.1595

${ }^{1}$ Department of Orthopedic surgery, Faculty of Medicine, Al-Azhar

University, Egypt

\begin{abstract}
Background: Lateral end clavicular fractures represent about $15 \%$ of clavicular fractures. Nonunion rate is about 22 to $44 \%$ due to interacting forces between arm weight and trapezius muscle.

Aim of the work: To assess the clinical and radiological outcomes of fixation by HP versus TBW and to determine which technique provides enough stability to permit early range of motion.

Patients and Methods: A prospective comparative study was done on 40 patients (20 patients fixed by HP and others 20 by TBW) and followed up at Al-Azhar University Hospitals between December 2019 to April 2021.

Result: The mean age of patients was 35.5 years in HP group and 37.4 years in TBW group with predominance in males than females ( 25 males and 15 females). Bone union occurred in $37(92 \%)$ of cases and non union occurred in $2(5 \%)$ cases in TBW group and $1(2.5 \%)$ case in HP group with average union time about 10 weeks in two groups and mean constant murley score was 86.5 in HP group and 87.6 in TBW group . Superficial infection occurred in 4 cases in TBW group (10\%) with no recorded cases in HP group.

Conclusion: Fixation of lateral end clavicular fractures using HP or TBW results in good functional outcome and low rate of complication where plating has many advantages such as minimal complications, easier technique and early motion of the affected shoulder.
\end{abstract}

Keywords: Tension; Band; Hook; lateral; clavicle.

Disclosure: The authors have no financial interest to declare in relation to the content of this article. The Article Processing Charge was paid for by the authors.

Authorship: All authors have a substantial contribution to the article.

\section{INTRODUCTION}

Clavicular fractures represent about $2.6 \%$ to $12 \%$ of all fractures and 44 to $66 \%$ of all shoulder fractures. Lateral third clavicular fractures account for $15 \%$. Clavicle is considered the junction between thoracic wall and upper limb, it receives large muscles insertions, and has an efficient role shoulder biomechanics. ${ }^{2}$ Clavicular fractures are classified into proximal, mid-shaft and distal fractures. Most of them are mid-shaft fractures that unite satisfactorily with non-operative treatment. It is important to recognize this distinct clavicle fracture as different entity and treat it properly. ${ }^{3}$ Most of lateral end clavicular fractures are minimally displaced and heal with proper functional outcome when non-operative treated. Fractures with complete displacement are less common but have a higher risk of subsequent nonunion. Most of displaced fractures occur in elderly patients and may have a satisfactory outcome after non-operative treatment in a low functional demands patients. ${ }^{4}$ Minorities of patients are younger so the operation is recommended as a primary treatment and may develop loss of strength, pain, decreased range of motion if non union occurred with non-operative treatment. ${ }^{4}$ Operative modalities include coraco-clavicular screws, TBW, HP, suspensory devices and locked plates. Complications of operative treatment may include non-union and mal-union fractures, pin migration, impingement of the plate, bleeding and plate removal. ${ }^{5}$

The aim of this study is to analyze and compare the results of fixation of lateral end clavicular fractures using HP versus TBW and to determine which technique provides good motion, stability and subsequently fracture union and complication rate.

\section{PATIENTS AND METHODS}

All patients in this study were managed and followed up at Al-Azhar University Hospitals. A prospective case series study was performed in a period between December 2019 to April 2021. Fourty 40 patients (25 males and 15 females) with fracture lateral end clavicle (Neer type II) were divided into two 2 groups; 1st group fixed by Hook Plate (HP)and 2nd group fixed by Tension Band Wire (TBW) with inclusion criteria (recent, extraarticular, unilateral, Neer II with normal function before trauma) while exclusion criteria (open, comminuted and pathological fractures). 
All patients were followed up for a minimum period average period of 12 months. of 11 months and maximum for 16 months with

\begin{tabular}{|c|c|c|c|c|c|c|c|}
\hline & & \multicolumn{2}{|c|}{ HP group $(\mathrm{N}=20)$} & \multicolumn{2}{|c|}{ TBW group $(\mathrm{N}=20)$} & Stat. test & P-value \\
\hline \multirow[t]{2}{*}{ Age(years) } & Mean & \multicolumn{2}{|c|}{35.5} & \multicolumn{2}{|c|}{37.4} & \multirow[t]{2}{*}{$\mathrm{T}=0.66$} & \multirow[t]{2}{*}{$0.510 \mathrm{NS}$} \\
\hline & $\pm \mathrm{SD}$ & & & & & & \\
\hline \multirow[t]{2}{*}{ Sex } & Male & 12 & $60 \%$ & 13 & $65 \%$ & \multirow[t]{2}{*}{$X^{2}=0.1$} & \multirow[t]{2}{*}{$0.744 \mathrm{NS}$} \\
\hline & Female & 8 & $40 \%$ & 7 & $35 \%$ & & \\
\hline \multirow[t]{2}{*}{ Occupation } & Heavy manual & 12 & $60 \%$ & 13 & $65 \%$ & \multirow[t]{2}{*}{$X^{2}=0.1$} & \multirow[t]{2}{*}{$0.744 \mathrm{NS}$} \\
\hline & Light manual & 8 & $40 \%$ & 7 & $35 \%$ & & \\
\hline \multirow[t]{2}{*}{ Side } & Right & 11 & $55 \%$ & 10 & $50 \%$ & \multirow[t]{2}{*}{$\mathrm{X}^{2}=0.1$} & \multirow[t]{2}{*}{$0.752 \mathrm{NS}$} \\
\hline & Left & 9 & $45 \%$ & 10 & $50 \%$ & & \\
\hline \multirow[t]{2}{*}{ DM } & No & 17 & $85 \%$ & 18 & $90 \%$ & \multirow[t]{2}{*}{$X^{2}=0.22$} & \multirow[t]{2}{*}{$0.633 \mathrm{NS}$} \\
\hline & Yes & 3 & $15 \%$ & 2 & $10 \%$ & & \\
\hline \multirow[t]{2}{*}{ Smoking } & No & 11 & $55 \%$ & 13 & $65 \%$ & \multirow[t]{2}{*}{$X^{2}=0.41$} & \multirow[t]{2}{*}{$0.519 \mathrm{NS}$} \\
\hline & Yes & 9 & $45 \%$ & 7 & $35 \%$ & & \\
\hline \multirow{2}{*}{$\begin{array}{l}\text { Mode of } \\
\text { trauma }\end{array}$} & RTA & 17 & $85 \%$ & 18 & $90 \%$ & \multirow[t]{2}{*}{$X^{2}=0.22$} & \multirow[t]{2}{*}{$0.633 \mathrm{NS}$} \\
\hline & Falling down & 3 & $15 \%$ & 2 & $10 \%$ & & \\
\hline \multirow[t]{2}{*}{ Dominant hand } & Right & 18 & $90 \%$ & 19 & $95 \%$ & \multirow[t]{2}{*}{$X^{2}=0.3$} & \multirow[t]{2}{*}{$0.548 \mathrm{NS}$} \\
\hline & Left & 2 & $10 \%$ & 1 & $5 \%$ & & \\
\hline
\end{tabular}

Table 1: Comparison between studied groups as demographic data.

\section{Clinical assessment}

Clavicle fractures typically induce pain, swelling, bruising and obvious deformity with limited range of motion with neurovascular examination to exclude brachial plexus or vascular injury.

Radiological investigation:

a single antero-posterior view erect position to demonstrate maximal deformity of the clavicle by the effect of gravity especially when considering surgery with chest radiograph to evaluate the deformity relative to the normal side.

\section{Surgical approach}

Hook plate method

Skin incision about $7 \mathrm{~cm}$ was done along anterior border then soft tissue dissection down to the bone, periosteal elevation, exposure of fracture ends then reduction maintained by reduction clamp and fixation of the fracture by AO hook plate which was placed along superior surface and inserted behind acromion process then irrigation of the wound by saline $0.9 \%$ was performed then covering of wound with dressing was done after closure.

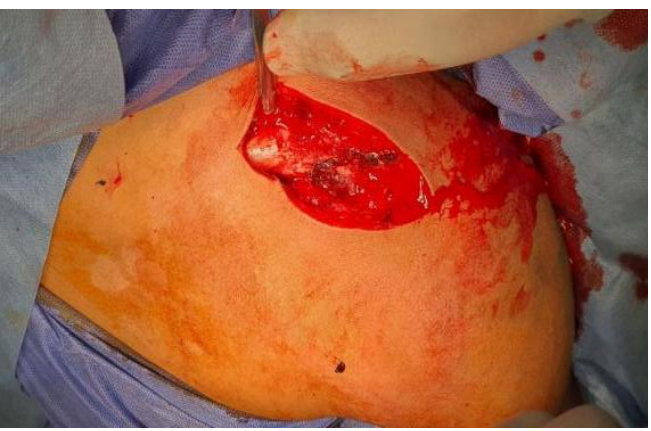

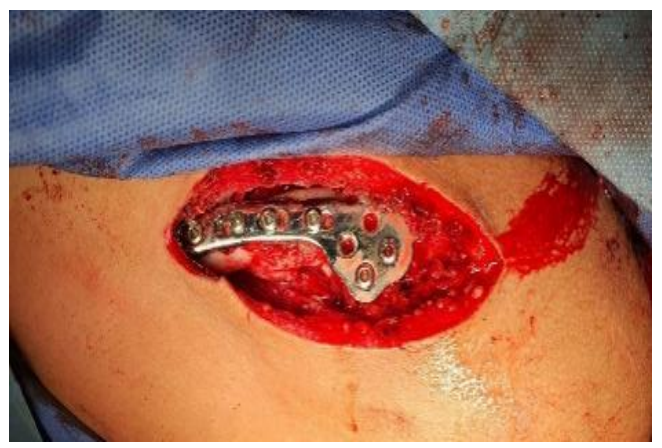

Fig. 1: A picture showing incision and fixation of lateral end clavicular fracture hook plate.

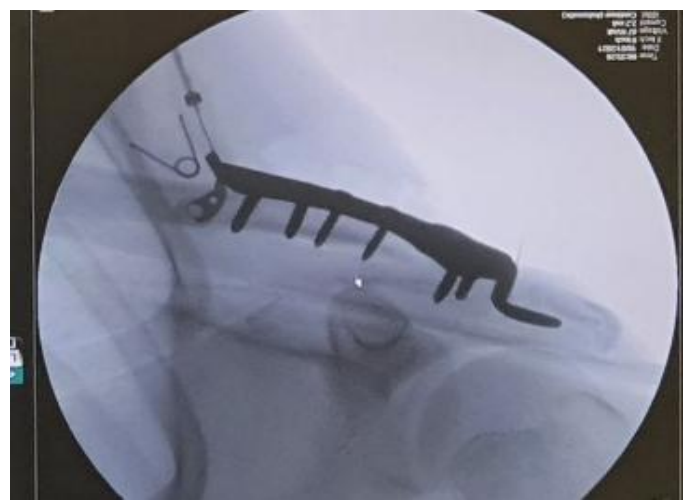

Fig. 1: fluroscopic image showing fixation of lateral third clavicle by hook plate.

Tension band wire method

Skin incision about $7 \mathrm{~cm}$ was done along anterior border then soft tissue dissection down to the bone, periosteal elevation, exposure of fracture ends and reduction maintained by reduction clamp. Under carm guidance, first $\mathrm{k}$-wire was inserted through anterior aspect of lateral end intramedullary and engaged into the posterior border and the second $\mathrm{k}$ wire was inserted through posterior aspect of lateral end intramedullary and engaged into the anterior border. 3.2 Drill Bit was done proximal to k-wire ends anterio-posteriorly to put transosseus tention 
band to augment and overcome migration. Then closure of the wound by layers.
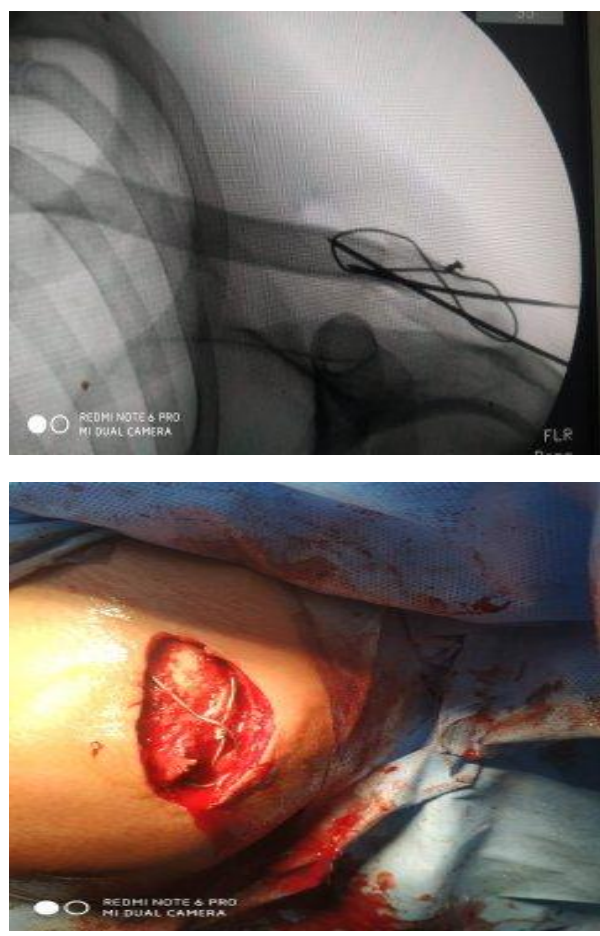

Fig. 3: Tension band wire insertion under image.

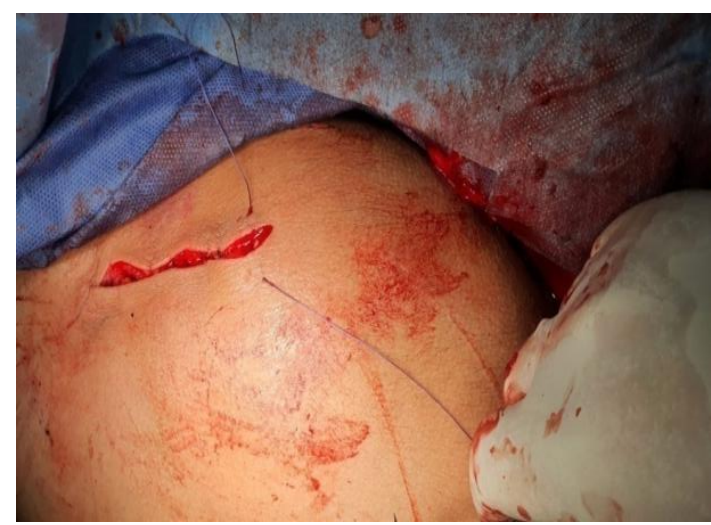

Fig. 4: Wound closure

Post-operative care and follow up

Antibiotics for 48 hours with arm sling applied for 2 to 3 weeks then removal of stitches was done after 2 weeks at least provided that wound healing was complete. Passive motion was initiated second day after surgery as tolerated in the form of pendulum exercises and active motion was initiated after 3 weeks as tolerated with regular visits in amanar of 2 weeks, 1 month, 3months and 6months postoperatively.

\section{Methods of assessment}

The patient was evaluated clinically and radiologically for at least 6 months and comparison was done according to operative time, union time, constant-Murley score and complication.

\section{RESULTS}

According to operative time and union time there was no significant difference between studied groups as $\mathrm{P}$ value $>.001$. According to Costant-Murley score, there was highly significant difference between studied groups as $\mathrm{P}$ value $<.001$.

\begin{tabular}{|c|c|c|c|c|c|}
\hline & & $\begin{array}{c}\mathrm{HP} \\
\text { group } \\
(\mathrm{N}= \\
20)\end{array}$ & $\begin{array}{c}\text { TBW } \\
\text { group } \\
(\mathrm{N}= \\
20)\end{array}$ & $\begin{array}{l}\text { Stat. } \\
\text { test }\end{array}$ & $\begin{array}{c}\mathrm{P}- \\
\text { value }\end{array}$ \\
\hline \multirow{3}{*}{$\begin{array}{l}\text { Operative } \\
\text { time(min) }\end{array}$} & Median & 77.5 & 70 & MW & 0.242 \\
\hline & IQR & $\begin{array}{c}70- \\
80\end{array}$ & $\begin{array}{c}61.25 \\
-80\end{array}$ & $\begin{array}{c}= \\
156.5\end{array}$ & NS \\
\hline & & $\begin{array}{c}\mathrm{HP} \\
\text { group } \\
(\mathrm{N}= \\
20)\end{array}$ & $\begin{array}{c}\text { TBW } \\
\text { group } \\
(\mathrm{N}= \\
20)\end{array}$ & $\begin{array}{l}\text { Stat. } \\
\text { test }\end{array}$ & $\begin{array}{c}\mathrm{P}- \\
\text { value }\end{array}$ \\
\hline \multirow{2}{*}{$\begin{array}{l}\text { Union } \\
\text { time(weeks) }\end{array}$} & Median & 10 & 10 & MW & 1.0 \\
\hline & IQR & $9-12$ & $9-12$ & $\begin{array}{c}= \\
200\end{array}$ & NS \\
\hline
\end{tabular}

\begin{tabular}{cccccc}
\hline & & $\begin{array}{c}\text { HP } \\
\text { group } \\
(\mathrm{N}= \\
20)\end{array}$ & $\begin{array}{c}\text { TBW } \\
\text { group } \\
(\mathrm{N}=\end{array}$ & $\begin{array}{c}\text { Stat. } \\
\text { test }\end{array}$ & P-value \\
& & $20)$ & & \\
\hline Constant- & Median & 86.5 & 87.6 & MW & $0.221 \mathrm{NS}$ \\
$\begin{array}{c}\text { Murley } \\
\text { Score }\end{array}$ & IQR & $\begin{array}{c}84- \\
89\end{array}$ & $\begin{array}{c}85.25 \\
=\end{array}$ & $=$ & \\
\hline
\end{tabular}

Table 2: Comparison between studied groups as regard operative time, union time and CostantMurley score.

According to complications, there were significant differences between studied groups as regard symptomatic hardware, subacromial impingment, coracoclavicular widening and wound infection due to $\mathrm{P}$ value $<0.05$ and non-significant differences according to implant failure, osteolysis and shoulder impingment as $\mathrm{P}$ value $>0.05$.

\begin{tabular}{|c|c|c|c|c|c|c|c|}
\hline & & & $\begin{array}{l}\text { group } \\
=20)\end{array}$ & & $\begin{array}{l}3 \mathrm{~W} \\
\text { oup } \\
=20 \text { ) }\end{array}$ & $\begin{array}{l}\text { Stat } \\
\text {. } \\
\text { test }\end{array}$ & $\begin{array}{c}\text { P- } \\
\text { valu } \\
\text { e }\end{array}$ \\
\hline \multirow{2}{*}{$\begin{array}{l}\text { Symptomatic } \\
\text { hard ware }\end{array}$} & No & $\begin{array}{l}1 \\
7\end{array}$ & $85 \%$ & $\begin{array}{l}1 \\
0\end{array}$ & $50 \%$ & \multirow{2}{*}{$\begin{array}{c}\mathrm{X}^{2} \\
= \\
5.6\end{array}$} & \multirow{2}{*}{$\begin{array}{l}0.01 \\
8 \mathrm{~S}\end{array}$} \\
\hline & Yes & 3 & $15 \%$ & $\begin{array}{l}1 \\
0\end{array}$ & $50 \%$ & & \\
\hline \multirow{2}{*}{$\begin{array}{l}\text { Subacromial } \\
\text { impingment }\end{array}$} & No & $\begin{array}{l}1 \\
3 \\
\end{array}$ & $65 \%$ & $\begin{array}{l}2 \\
0\end{array}$ & $\begin{array}{c}100 \\
\%\end{array}$ & $\begin{array}{l}\mathrm{X}^{2} \\
=\end{array}$ & \multirow{2}{*}{$\begin{array}{l}0.00 \\
3 \mathrm{~S}\end{array}$} \\
\hline & Yes & 7 & $35 \%$ & 0 & $0 \%$ & 8.5 & \\
\hline \multirow{2}{*}{$\begin{array}{l}\text { Coracoclavicul } \\
\text { ar widening }\end{array}$} & No & $\begin{array}{l}2 \\
0 \\
\end{array}$ & $\begin{array}{c}100 \\
\%\end{array}$ & $\begin{array}{l}1 \\
4 \\
\end{array}$ & $70 \%$ & \multirow{2}{*}{$\begin{array}{c}\mathrm{X}^{2} \\
= \\
7.0 \\
5\end{array}$} & \multirow{2}{*}{$\begin{array}{l}0.00 \\
7 \mathrm{~S}\end{array}$} \\
\hline & Yes & 0 & $0 \%$ & 6 & $30 \%$ & & \\
\hline \multirow{2}{*}{$\begin{array}{l}\text { Implant } \\
\text { failure }\end{array}$} & No & $\begin{array}{l}1 \\
8\end{array}$ & $90 \%$ & $\begin{array}{l}1 \\
6\end{array}$ & $80 \%$ & \multirow{2}{*}{$\begin{array}{c}\mathrm{X}^{2} \\
= \\
0.7 \\
8\end{array}$} & \multirow{2}{*}{$\begin{array}{c}0.37 \\
5 \\
\text { NS }\end{array}$} \\
\hline & Yes & 2 & $10 \%$ & 4 & $20 \%$ & & \\
\hline \multirow{2}{*}{$\begin{array}{l}\text { Distal clavicle } \\
\text { osteolysis }\end{array}$} & No & $\begin{array}{l}1 \\
9 \\
\end{array}$ & $95 \%$ & $\begin{array}{l}2 \\
0 \\
\end{array}$ & $\begin{array}{c}100 \\
\%\end{array}$ & \multirow{2}{*}{$\begin{array}{c}\mathrm{X}^{2} \\
= \\
1.0 \\
2\end{array}$} & \multirow{2}{*}{$\begin{array}{c}0.31 \\
1 \\
\text { NS }\end{array}$} \\
\hline & Yes & 1 & $5 \%$ & 0 & $0 \%$ & & \\
\hline \multirow{2}{*}{$\begin{array}{l}\text { shoulder } \\
\text { impingement }\end{array}$} & No & $\begin{array}{l}2 \\
0 \\
\end{array}$ & $\begin{array}{c}100 \\
\%\end{array}$ & $\begin{array}{l}1 \\
9 \\
\end{array}$ & $95 \%$ & \multirow{2}{*}{$\begin{array}{c}\mathrm{X}^{2} \\
= \\
1.0 \\
2\end{array}$} & \multirow{2}{*}{$\begin{array}{c}0.31 \\
1 \\
\text { NS }\end{array}$} \\
\hline & Yes & 0 & $0 \%$ & 1 & $5 \%$ & & \\
\hline \multirow{2}{*}{$\begin{array}{l}\text { Wound } \\
\text { infection }\end{array}$} & No & $\begin{array}{l}2 \\
0 \\
\end{array}$ & $\begin{array}{c}100 \\
\%\end{array}$ & $\begin{array}{l}1 \\
6 \\
\end{array}$ & $80 \%$ & \multirow{2}{*}{$\begin{array}{c}\mathrm{X}^{2} \\
= \\
4.4 \\
4\end{array}$} & \multirow{2}{*}{$\begin{array}{l}0.03 \\
5 \mathrm{~S}\end{array}$} \\
\hline & Yes & 0 & $0 \%$ & 4 & $20 \%$ & & \\
\hline
\end{tabular}

Table 3: Comparison between studied groups as regard complications. 


\section{Cases Presentation}

Case 1

Male patient 36 yrs old with distal end clavicular fracture fixed by hook plate.

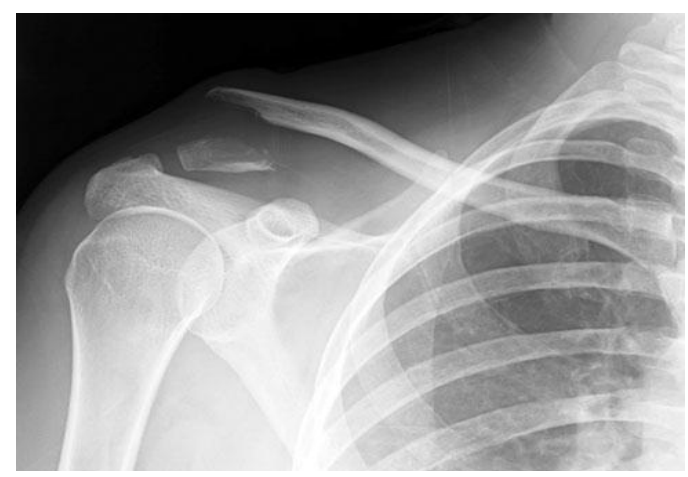

Fig. 5: preoperative $x$ ray.

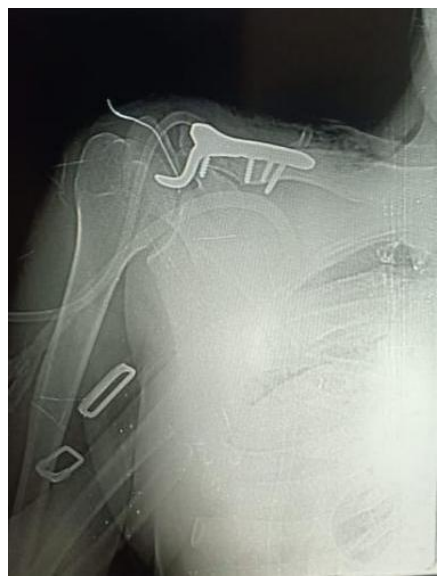

Fig. 6: Immediate post operative x-ray.

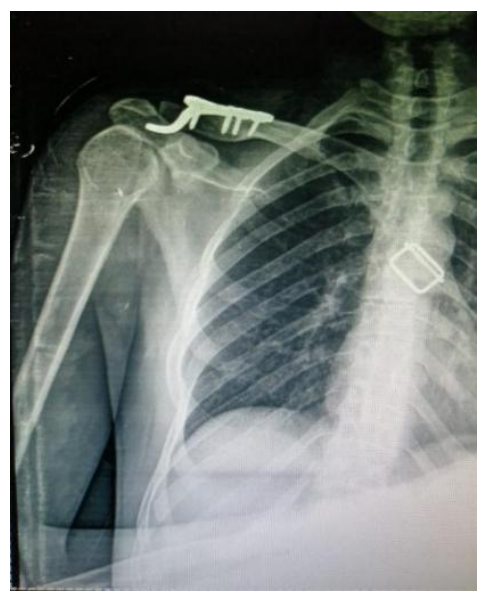

Fig. 7: Four months post operative.
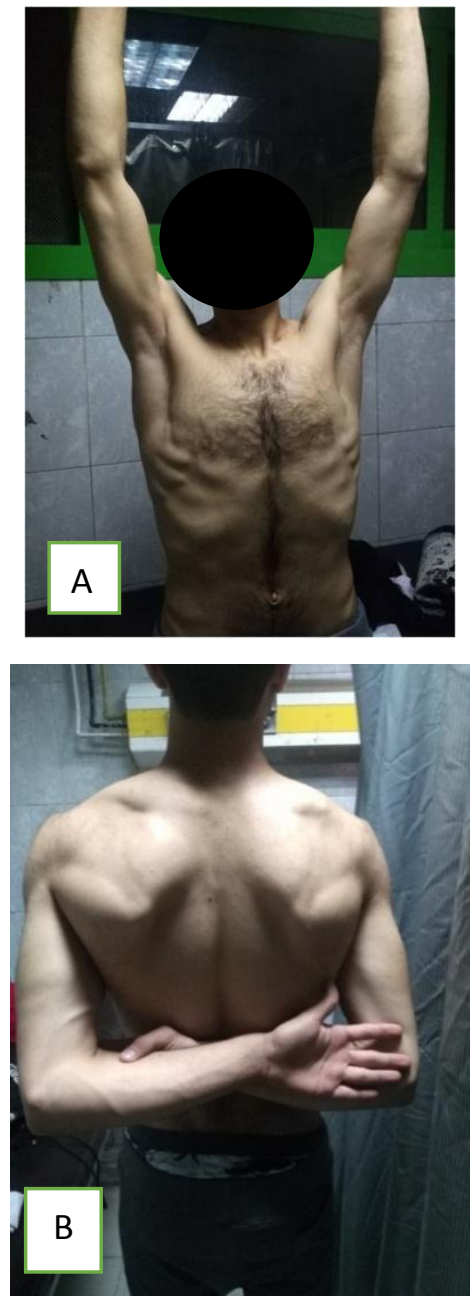

Fig. 8: a-b showing ROM after removal.

Case 2

Female patient 38 yrs old with distal end clavicular fracture fixed by TBW.

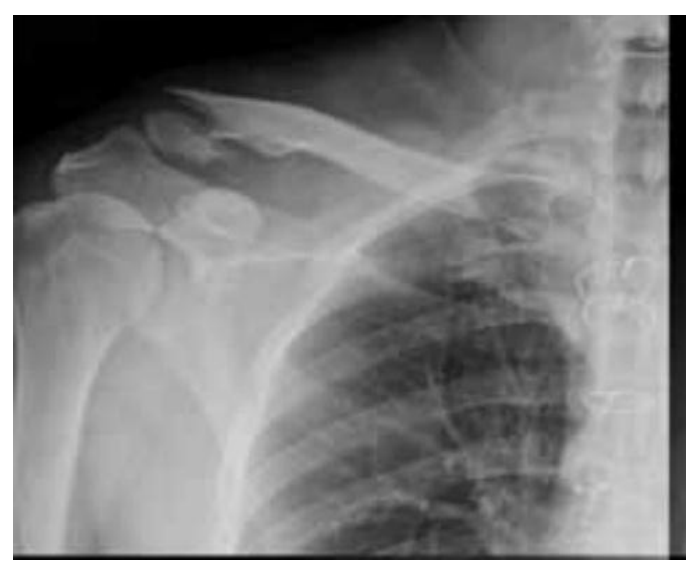

Fig. 9: Pre operative x-ray. 


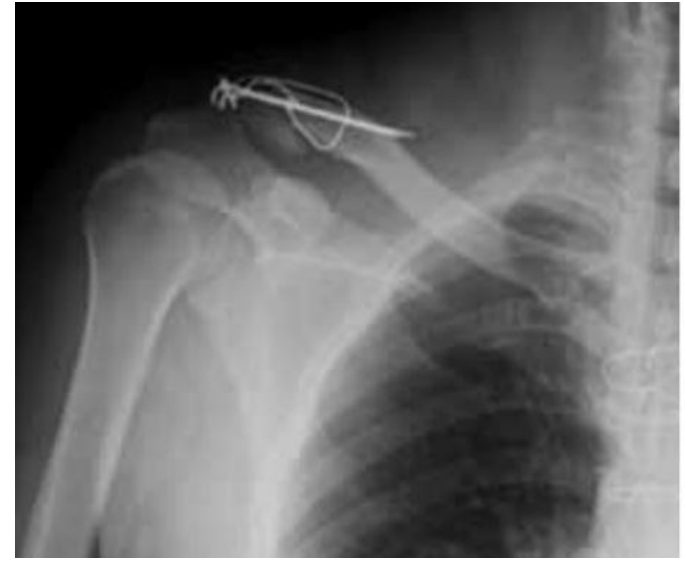

Fig. 10: Immediate Post operative $x$ ray.

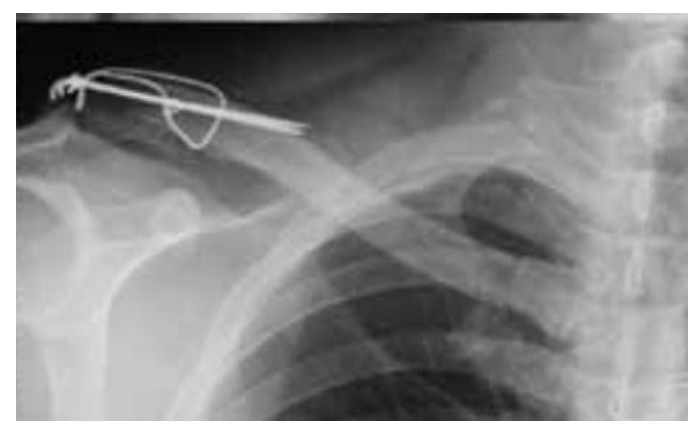

Fig. 11: 4 months post operative $\mathrm{x}$-ray.

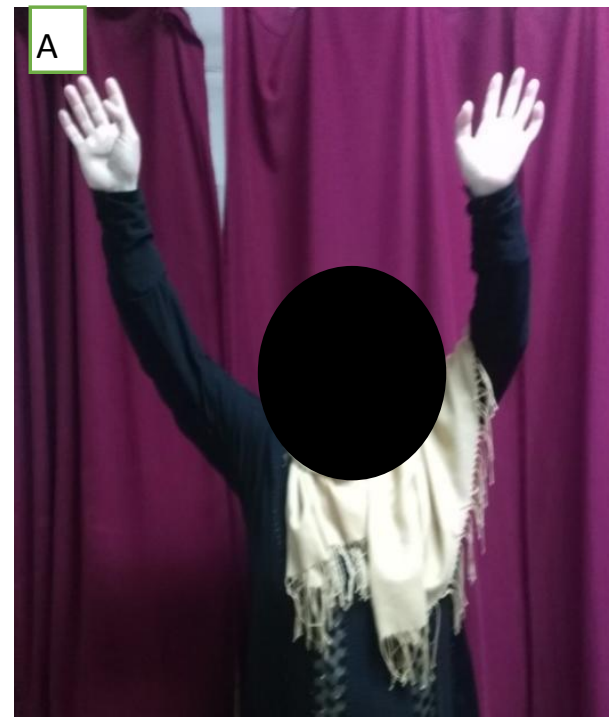

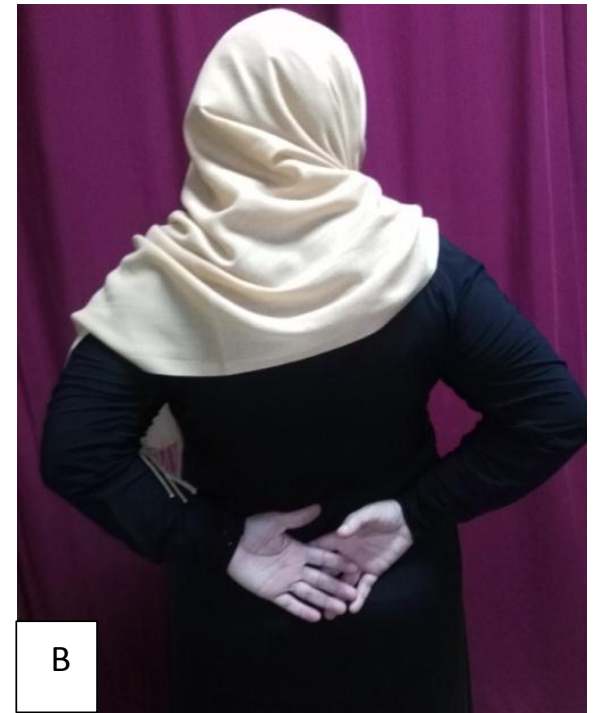

Fig. 12: a-b showing ROM post removal.

\section{DISCUSSION}

Comparison between two types of treatment with reasonable sample sizes in distal clavicular fracture is chalenging. Its anatomical properties (narrow, less dense ) make fixation with screws difficult. The subcutaneous position gives rise to skin irritation caused by the implants thus requires removal. ${ }^{6}$ All fixation methods have superiorities or deficiencies when compared to each other and none of them has been nominated as the 'gold standard. ${ }^{7}$ In this study, lateral end clavicular fracture Neer type II was more common among young active patients. The patients age ranged from 23 years old to 54 years old with mean age of 35.5 years in hook plate group and 37.4 years in TBW group and this is comparable to Daglar B,et al. ${ }^{8}$ in which the mean age was $29,8 \pm 8,7$ years (range 19-51), also comparable to Daniel W, et al .? in which the mean age was 36.2 years range (22-60) years and Kalamares $\mathrm{M}$, et al. ${ }^{10}$ in which the mean age was 28.8 years range from (16 to 41 ). In this study, lateral end clavicular fracture Neer type II is predominant in males than females as the study included 25 males and 15 females and this is comparable to Daglar et al.$^{8}$ which included 11 males and 3 females, also comparable to Daniel et al . which included 26 males and 10 females and to Kalamares et al.$^{10}$ which included 7 males and 2 females. In this study, bone union occured in 37 cases $(92 \%)$ and non union occurred in 2 cases (5\%) in TBW group due to implant failure and infection and 1 case $(2.5 \%)$ in hook plate group due to implant failure. The bone union was 10 weeks avarage in two groups (Ranged from 9 to 12 weeks) and this is comparable to Daniel et al. ${ }^{9}$ in which the rate of union was $95 \%$ with 3 months avarage union time. In this study, all patients acquired satisfactory motion range compared to the normal side with excellent shoulder function. Mean constant murley score was 86.5 in HP group (ranged from 84 to 89 ) and 87.6 in TBW group (ranged from 85.25-90) so, this indicates a satisfactory joint function and This is comparable to Daglar et al . ${ }^{9}$ in which the mean Constant score was $95.4 \pm 3.0$ at 12 months and this mean excellent shoulder function according to these scores. There 
was a good results in most of patients. The best results were obtained when the HP was removed before 6 months, which was done in most of cases and This is also comparable to Kalamares et al.$^{10}$ in which the mean constant shoulder score was 96 . These results may be due to use of this type of fixation that allows early rehabilitation resulting in normal range of motion. In this study, infection was recorded in 4 cases with TBW fixation (10\%) and was controlled with antibiotics with no recorded cases in HP group and this is comparable to Kalamares et al. ${ }^{10}$ in which wound infection occurred in one case (11\% of cases).

\section{CONCLUSION}

Surgical treatment of lateral end clavicular fractures using different methods of fixating results in a good functional outcome with low complication rate. Plating of lateral third clavicular fractures has many advantages such as easy application, less complications, short stay in hospital and early mobilization of the affected shoulder.

\section{REFERENCES}

1. Egol KA, Koval KJ and Zuckerman JD. clavicle fractures, Handbook of fractures. $4^{\text {th }}$ Ed. 2010. $\mathrm{p}: 141-9$.

2. Havet E, Duparc F and Muller JM: Vascular anatomical basis of clavicular non-union. Surg Radiol Anat. 2008; 30:23-8.

3. Allman FL. Fractures and ligamentous injuries of the clavicle and its articulation. JBone Joint Surg Am, 1967;49(4): 774-84.
4. Robinson CM and Cairns DA. Primarynon operative treatment of displaced lateral fractures of the clavicle. J Bone Joint Surg Am 2004; 86:778-82.

5. Raju Vaishya, Vipul Vijay and Vikram Khanna. Outcome of distal end clavicle fractures treated with locking plates. Chinese Journal of Traumatology. 2017:P 45-48.

6. Souza Vilela JC, de Andrade RP, Jacques Gonçalves LB, et al. Fractures of the distal clavicle: comparison between two surgical treatment methods. Revista Brasileira de Ortopedia (English Edition), 2015; 50(2):13641.

7. Şükür E, Öztürkmen Y, Akman YE, et al. Clinical and radiological results on the fixation of Neer type 2 distal clavicle fractures with a hook plate. Acta Orthopaedica et Traumatologica Turcica. 2016; 50(5): 489-93.

8. Daglar B, Onder M, Emre Minareci, et al. An alternative fixation method for the treatment of unstable distal clavicle fractures: locked distal radius plate. Acta Orthop Traumatol Turc. 2009; 43(4):324-30.

9. Daniel W, Darren F, Michael L, et al. Clavicle hook plate fixation for displaced lateral-third clavicle fractures (Neer type II): a functional outcome study. J Shoulder Elbow Surg, 2012; 21:1045-48.

10. Kalamares M, Cutbush K and Robinson M. A method for internal fixation of unstable distal clavicle fractures: early observations using a new technique. J Should ElbSurg; 2008; 17:602. 